\title{
Advancing the IS Curricula: The Identification of Important Communication Skills Needed by IS Staff During Systems Development
}

\author{
Ruth A. Miller and Donna W. Luse \\ The University of Louisiana at Monroe, Monroe, Louisiana, USA
}

\section{miller@ulm.edu luse@ulm.edu \\ Executive Summary}

Although research indicates communication is important among information systems (IS) staff, users, and managers to ensure successful development projects, the ineffective communication skills of IS staff are often cited as a possible cause of failed IS projects. To develop effective systems, communication between IS users and systems developers is important throughout the development process, and effective communication supports the collaborative process in system development. As found in the IS 2002 model curriculum, IS experts place interpersonal, communication, and team skills as one of four main categories of exit characteristics of IS graduates (Gorgone et al., 2002). Since effective communication among IS project stakeholders is cited as a critical factor of project success, this study identified specific written, oral, and interpersonal communication skills IS staff, IS users, and IS managers perceived to be the most important for IS staff during the systems development process.

To investigate the most important communication skills needed by IS staff during the development process, IS staff, IS users, and IS managers who worked on a system development project together were surveyed. Results of the data obtained from the 324 respondents were analyzed in two ways: first, the most important communication skills needed by IS staff were ranked by each participant category and, second, models of the three communication skill types were developed through confirmatory factor analysis (CFA). Rankings by IS users, IS staff, and IS managers, as presented in this study, indicated that the three stakeholder groups had similar views of critical written, oral, and interpersonal communication skills needed by IS staff in the systems development process. Respondents consistently identified the most important writing skill as coherent writing, the two most important oral communication skills as the ability to ask appropriate questions and have effective oral communication skills, and the two most important interpersonal skills as the ability to accomplish assignments and the ability to work cooperatively in a one-onone and project team environment.

Using CFA, a written communication skill model consisting of 18 items was identified, an oral communication skill model consisting of 6 items was identified, and an interpersonal communica-

Material published as part of this journal, either on-line or in print, is copyrighted by the publisher of the Journal of Information Technology Education. Permission to make digital or paper copy of part or all of these works for personal or classroom use is granted without fee provided that the copies are not made or distributed for profit or commercial advantage AND that copies 1) bear this notice in full and 2) give the full citation on the first page. It is permissible to abstract these works so long as credit is given. To copy in all other cases or to republish or to post on a server or to redistribute to lists requires specific permission and payment of a fee. Contact Editor@JITE.org to request redistribution permission. tion skill model consisting of 7 items was identified. The CFA procedure and comparisons with other studies provided support for the validity and reliability for the proposed constructs developed for important written, oral, and interpersonal communication skills.

Both the rankings and confirmatory factor analysis models presented in 
Advancing the IS Curricula: The Identification of Important Communication Skills

this study provide IS faculty a set of important communication skills to use when nurturing and refining students' skills to enhance their employability and reduce project risk associated with poor communication among project stakeholders. Incorporating the most paramount communication skills within an IS curriculum is vital to produce effective IS graduates.

Keywords: IS staff communication skills, IS project development skills, information systems skills, IS curriculum, IS education, written communication skills, oral communication skills, interpersonal communication skills

\section{Introduction}

In the past, computer scientists frequently developed systems that were not acceptable to the users of the system, which is why information technology curricula were developed in business schools (Mann, 2002). These problematic systems often resulted from interaction difficulties between developers and users of the system (Averett, 2001). In the traditional approach of developing systems, the systems analyst only interviewed the end user to determine the needs of a proposed system (Kohli \& Grupta, 2002). The system developer then built the most efficient, economical, and effective system possible. In today's dynamic, globally competitive environment, however, such an “economical” approach to systems development cannot survive (Lee, Trauth, \& Farwell, 1995).

Even though numerous information systems (IS) programs are producing graduates from business schools, the number of ineffective systems is still too high (Mann, 2002). Because many completed systems are inadequately used or are abandoned (Ewusi-Mensah, 1997), the systems end in failure ('Time to Share Risks', 1999). In addition to these failed systems, industry experts indicate that many IS development projects are canceled prior to completion. Clark (2002), in a study of 134 companies in the United States, United Kingdom, Africa, and Australia, found that 56 percent of the companies had cancelled at least one IS project during the last year at an average cost of US \$13.6 million. At an American Management Association Conference, Jerome Jewell, former IBM Corporation manager and president/founder of Jewell Consulting Group, stated, "some argue that information technology (IT) has created a breed of managers who have lost the art of human interaction and who immerse themselves in information based technologies rather than focusing on the value that information can provide for clients” (Verespej, 1999, p. 22).

\section{Need for Communication Skills}

Technology issues or technical skills of IS staff often do not appear to be the problem for these failed systems; instead, researchers are finding ineffective communication skills may be a contributing factor. One recent study found the current IS technology knowledge/skills, such as programming languages, packaged products, hardware, and operations systems, that IS graduates possess is adequate (Yen, Lee, \& Koh, 2001). However, interpersonal and personal trait knowledge/skills, such as interpersonal, communication, and critical thinking skills, of IS graduates are also very important. A possible cause, then, of failed or inadequate systems may be ineffective communication skills of information systems staff as they interact with IS users during project development. As Clark (2002) found, 67 percent of the respondents in his study indicated project failure was due to poor communication, inadequate planning, and poor scope management.

Many recent studies point to the critical nature of communication skills of IS staff in systems development to help ensure project success. Some studies indicate that communication skills are even more critical in systems development than technical skills (Ehie, 2002; Snoke \& Underwood, 2001). Ehie found that congruent with the increasing demand for MIS graduates is the market's increased expectations of knowledge, skills, and abilities by these graduates. He stated that employers are 
looking for graduates with good communications and people skills. ... Although technical-oriented skills were considered important, business-oriented skills were considered more important in hiring MIS graduates. In the words of one practitioner, 'We can train our new MIS hire on the technical skills, but it is very difficult to teach him or her interpersonal and communication skills' (Ehie, 2002, p. 154).

In support of the importance of communication skills for IS graduates, the model curriculum proposed by IS 2002 places interpersonal, communication, and team skills as one of four main categories of exit characteristics of IS graduates (Gorgone et al., 2002). A second main category of exit characteristics of IS graduates is analytical and critical thinking skills, which incorporates fundamental skills needed by individuals to effectively communicate throughout the development process.

When studying project risk variables that had the most influence on IS project development satisfaction, Jiang and Klein (1999) deduced that effective communication between IS users and IS development staff was one of four critical factors of project success. They further concluded that for each system development project, the IS staff needed appropriate communication skills to interact successfully with IS users and IS managers to enhance user satisfaction. Thus, IS graduates today must be able to view business processes from the more current, integrative perspective rather than from a functional perspective, and they "should be able to work with a company's clients, understand their needs, and be able to develop information systems that would solve the clients' problems” (Ehie, 2002, p. 155).

\section{Need for Collaborative Skills}

In addition to better communication skills, teamwork and collaborative skills will be needed by IS developers to construct successful systems. In the on-going discussion in IS literature on the importance of collaboration to the development process, as far back as 1988 Guinan concluded that effective communication supports the collaborative process in systems development. More recently, when looking at how information professionals can achieve excellence, Bennett (1999) noted that one of the top factors leading to management success today and into the next century is being able to work synergistically in a team. And, from their research, Noll \& Wilkins (2002, p. 1) found that “... soft skills, such as teamwork and collaboration, planning and leading projects, presentation delivery, and writing skills will be critical for success in the information systems profession."

Contributing to unsuccessful collaboration by IS staff, IS users, and IS managers are the varied and divergent backgrounds of these stakeholders. Because of their varied backgrounds, education, and functional orientations, IS staff, IS users, and IS managers may have different goals and expectations of the systems development process. In looking at the interaction process that occurs among participants in IS development, the following management and social interaction theories support this conviction.

By applying Freeman's (1986) stakeholder approach to project management activities, one would conclude that IS project development activities must include all of the groups and individuals who can affect a project and must allow for managerial behavior to direct those groups or individuals. Mintzberg's work (1997) supports this approach since he believes that users possess the information on the environmental dynamics while specialists, such as IS staff, would have the time and aptitude to conduct required systematic analysis and design.

However, even though all stakeholders may be involved in creating a system, barriers may exist that prevent effective system development. For example, based on agency theory (Jensen \& Meckling, 1976), IS users are often viewed as principals who contract with IS staff to develop 
Advancing the IS Curricula: The Identification of Important Communication Skills

information systems, and the IS users are dependent on the actions of the IS staff (the agents). Because system development is a complex field which requires specialization that is not well known to or understood by IS users, IS staff might attempt to influence the outcome of the project development with little regard for the user's specific desires. According to Jiang, Klein, and Sobol (2000), social perception research indicates that different work environments and/or individual differences may affect people's perceptions and that there may be a difference in perceptions of people who do not have similar schemas. If a system is designed under these circumstances, with little collaboration or communication, IS developers are assuring the designed system will be ineffective.

According to Suchan and Dulek’s (1998) open systems model of communication in business, the effectiveness of the communication process is impacted by internal and external environmental factors. One such environmental factor is the power to influence others. Because of the complex, specialized knowledge of IS staff, the IS staff might exert significant influence over other IS project development team members, especially IS users, if IS staff are not able to effectively communicate and collaborate.

Furthermore, according to Locke's original goal-setting theory (1969), people have needs that are expressed as specific outcomes or goals they hope to accomplish. For example, Daft (1994) found that when individuals worked together on a team, such as project development, conflict occurred simply because team members were pursuing different goals. Thus, even though all stakeholders may be participating throughout the systems development process, each different stakeholder may have different goals. Consequently, IS developers must use effective communication skills and collaborate with the users to flesh out common goals to help ensure a usable system is designed. This need is further supported by the IS 2002 model curriculum proposing interpersonal, communication, and team skills within the IS curriculum (Gorgone et al., 2002).

Researchers have concluded that communication between IS users and system developers is important throughout the development process for producing effective systems and that effective communication supports the collaborative process in system development. However, little research exists that identifies the specific communication skills needed throughout this process. To help advance better designed IS curricula for IS graduates, the specific communication skills perceived by project stakeholders to be important during the project development process need to be identified. Thus, this study investigates and identifies the important written, oral, and interpersonal communication skills needed by information systems staff in producing system development projects.

\section{Method}

Employees at various companies from the southeastern area of the United States in the states of Texas, Louisiana, and Mississippi completed a survey. Because the survey instrument was lengthy, to promote participation and to maintain confidentiality of responses to sensitive questions, the geographic area was confined and researchers personally picked up completed questionnaires. Observations used for analysis in this study consisted of responses from three employees at each location, including a member of the IS staff, an IS user, and the IS manager, who worked on a system development project together. To obtain observations, initial contact with prospective participants was made in two ways-by contacting the IS director of a company or by contacting prospective survey participants (project development team members). Data presented here were collected over several years. A total of 324 questionnaires were analyzed.

The questionnaire was designed to gather the participants' perceptions of the importance of specific written, oral, and interpersonal communication skills needed by IS staff in the project development process. The questionnaire contained a demographic data section in addition to the scales 
used to measure the three communication skills constructs. The scales were developed through a review of the literature and based on the opinions of a panel of experts in business communication and in information systems (Lee, Trauth, \& Farwell, 1995; Maes, Weldy, \& Icenogle, 1997; Quible, 1991). The panel of experts consisted of two business communication professors and three information systems professors who teach in the College of Business Administration at two regional, Association to Advance Collegiate Schools of Business (AACSB) Internationalaccredited business schools in Louisiana. Using the input from this panel and from a pilot test (obtained from a sample of 7 observations of 21 participants), the instruments were refined and slight changes were made in the wording of items.

Written communication skills perceived to be important by IS staff in project development were measured using the 36-item scale developed by Quible (1991). This scale was selected because of the instrument's established content validity and internal reliability. The perceived importance of oral communication skills to IS staff in project development was measured by using six items derived from the opinions of experts in communication and prior research (Maes, Weldy, \& Icenogle, 1997). To measure the perceived importance of interpersonal skills to IS staff in project development, the researchers used nine items from the Interpersonal and Management Knowledge/Skills construct developed by Lee, Trauth, and Farwell (1995). This instrument was developed after Lee, Trauth, and Farwell comprehensively reviewed the recommendations of the Curriculum Committee of the Association for Computing Machinery. Perception of importance of each skill item on the three instruments was measured using a Likert-type five-point scale ranging from unimportant (1) to very important (5). (For access to raw data, contact Ruth Miller at miller@ulm.edu )

After collecting the data, communication variables were initially ranked based on importance by participant type-IS staff, IS user, and IS manager-to identify the most important communication skills needed by IS staff. Then, a confirmatory factor analysis (CFA) procedure was performed on each style of communication (written, oral, and interpersonal) to identify variable factors, evaluate validity and reliability of the variables, and confirm model fit of the research variables.

The CFA procedure was used because it analyzes the underlying patterns or relationships of the observed variables' scales to determine whether the information contained in each variable can be summarized into a model consisting of a smaller set of factors (Hair, Anderson, Tatham, \& Black, 1992). CFA also provides a method for examining the validity and reliability of the factors and for assessing how well the models fit the data.

In the CFA analysis, the correlations, or factor loadings, between observed variables and the factors were first analyzed. Any variable item with a 0.50 or higher loading on a specific factor and a loading no higher than 0.35 on other factors was retained (Igbaria \& Baroudi, 1995). Items not meeting these criteria were deleted from further analysis. Next, convergent validity, or homogeneity of the items that comprise a factor, was assessed by analyzing internal consistency reliability scores using Cronbach's alpha and using t-tests for significance. Discriminant validity, or the uniqueness (heterogeneity) of the factors measured by different sets of observed variable items, was established by analyzing the items' factor loadings and by performing confidence interval tests. Finally, a set of model measurement fit indices recommended by Kline (1998) was used to determine how well the written, oral, and interpersonal communication models established through CFA fit the research data. The indices used included the following:

- a measure to predict covariance (chi-square/degrees of freedom and its significance level),

- an index that shows the proportion in improvement of the overall fit of the researcher's model compared to a null model-Normed Fit Index (NFI), 
Advancing the IS Curricula: The Identification of Important Communication Skills

- an index that describes the overall proportion of explained variance-Bentler Comparative Fit Index (CFI),

- an index that adjusts the proportion of explained variance for model complexityBentler-Bonett Non-Normed Fix Index (NNFI),

- an index based on standardized residuals—Root Mean Square Residual (RMR).

(See the following sources for a thorough discussion of CFA: Campbell \& Fiske, 1959; Cronbach, 1951; Hair, Anderson, Tatham, \& Black, 1992; Igbaria \& Baroudi, 1995; and Kline, 1998.)

\section{Findings and Analysis}

A total of 324 participants, including IS managers (department managers and project leaders), IS staff (systems analysts and programmers), and IS users, completed the questionnaire. As shown in Table 1, IS staff respondents had less work experience than IS managers, and IS staff respondents were younger than IS managers and IS users. Additionally, almost 70\% of IS managers and IS staff were male, while almost $52 \%$ of the IS users were female. The IS managers and IS staff were also more educated than the IS users, with over $70 \%$ of IS personnel having completed

\begin{tabular}{|c|c|c|c|c|c|c|}
\hline & \multicolumn{2}{|c|}{$\begin{array}{c}\text { IS } \\
\text { MANAGER }\end{array}$} & \multicolumn{2}{|c|}{$\begin{array}{c}\text { IS } \\
\text { STAFF }\end{array}$} & \multicolumn{2}{|c|}{$\begin{array}{c}\text { IS } \\
\text { USER }\end{array}$} \\
\hline & $\mathrm{n}$ & $\%$ & $\mathrm{n}$ & $\%$ & $\mathrm{n}$ & $\%$ \\
\hline \multicolumn{7}{|l|}{ Work Experience: } \\
\hline$<10$ years & 39 & 36.1 & 63 & 58.3 & 51 & 46.3 \\
\hline$\geq 10$ and $<20$ & 33 & 30.6 & 35 & 32.4 & 36 & 47.2 \\
\hline$\geq 20$ and $<30$ & 28 & 25.9 & 6 & 5.5 & 14 & 4.6 \\
\hline$\geq 30$ & 5 & 4.6 & 2 & 1.9 & 5 & 0.0 \\
\hline No report & 3 & 2.8 & 2 & 1.9 & 2 & 1.9 \\
\hline Total & 108 & 100.0 & 108 & 100.0 & 108 & 100.0 \\
\hline \multicolumn{7}{|l|}{ Age: } \\
\hline$<30$ years old & 9 & 8.4 & 31 & 28.8 & 23 & 21.3 \\
\hline$\geq 30$ and $<40$ & 33 & 30.6 & 52 & 48.1 & 26 & 24.1 \\
\hline$\geq 40$ and $<50$ & 21 & 19.4 & 17 & 15.7 & 34 & 31.5 \\
\hline$\geq 50$ & 21 & 19.4 & 3 & 2.8 & 13 & 12.0 \\
\hline No report & 24 & 22.2 & 5 & 4.6 & 12 & 11.1 \\
\hline Total & 108 & 100.0 & 108 & 100.0 & 108 & 100.0 \\
\hline \multicolumn{7}{|l|}{ Gender: } \\
\hline Male & 72 & 66.7 & 75 & 69.4 & 49 & 45.4 \\
\hline Female & 32 & 29.6 & 32 & 29.7 & 56 & 51.8 \\
\hline No report & 4 & 3.7 & 1 & .9 & 3 & 2.8 \\
\hline Total & 108 & 100.0 & 108 & 100.0 & 108 & 100.0 \\
\hline \multicolumn{7}{|l|}{ Education: } \\
\hline Graduate degree & 18 & 16.7 & 14 & 13.0 & 10 & 9.3 \\
\hline Bachelor degree & 58 & 53.7 & 63 & 58.3 & 45 & 41.6 \\
\hline Some college & 20 & 18.5 & 20 & 18.5 & 36 & 33.3 \\
\hline Vocational school & 5 & 4.6 & 2 & 1.8 & 3 & 2.8 \\
\hline High School & 3 & 2.8 & 6 & 5.6 & 10 & 9.3 \\
\hline No report & 4 & 3.7 & 3 & 2.8 & 4 & 3.7 \\
\hline Total & 108 & 100.0 & 108 & 100.0 & 108 & 100.0 \\
\hline
\end{tabular}


higher educational degrees while less than $51 \%$ of IS users having completed similar degrees.

Results of the following data analyses are separated into two parts. First, the rankings of the most important communication skills needed by IS staff in the systems development process are discussed by type - written, oral, and interpersonal — for each participant category. Then, models of the three communication skill types developed through CFA are presented.

\section{Ranking Communication Skills}

Written, oral, and interpersonal communication skills needed by IS staff were ranked in descending order by the mean perceived importance. Because the scale ranged from $1=$ Unimportant to $5=$ =ery Important, only those skills with a mean of 4.0 or higher were considered to be more important. Since a main objective of IS professionals is to facilitate information technology usage by organizations in meeting "their strategic objectives with a customer service orientation" (Gorgone et al., 2002, p. 1), a customer-focused view is important in project design. As Ehie (2002, p. 154) stated, "MIS graduates should be able to work with a company's clients, understand their needs, and be able to develop information systems that . . . solve clients' problems.” Therefore, the following results are reported based on the IS user's top rankings as compared to the rankings of IS staff and IS managers.

As shown in Table 2, the rankings (by participant type-IS user as compared to IS staff and IS manager) of important written communication skills needed by IS staff in the systems development process show that coherent writing was unanimously rated as the most important writing skill, indicating clarity and understanding is paramount to ensuring effective system design. Although the ranking order varied overall, all three participant types consistently rated the same written communication skills-use words correctly, use effective arrangement of ideas, write concisely, organize material well, write decisively, use grammar correctly, and construct effective sentences-as being the most important skills needed by IS staff in the development process. However, a notable difference in the rank order of important skills was found relating to use of correct grammar. Although IS staff and IS managers ranked the use of correct grammar as being very important, ranking it $2^{\text {nd }}$ and $3^{\text {rd }}$ respectively, the IS users ranked this item in the lower third, or $7^{\text {th }}$, of the top ten items ranked. This may be due to credibility concerns the IS staff and IS managers may have in preparing a written document for the IS user audience, whereas the IS user

\begin{tabular}{|c|c|c|c|c|c|c|}
\hline \multicolumn{7}{|c|}{$\begin{array}{l}\text { TABLE 2: Important Written Communication Skills } \\
\text { Needed By Information Systems Staff } \\
\text { (Rankings By Participant Type) }\end{array}$} \\
\hline Skill & $\begin{array}{l}\text { IS } \\
\text { User } \\
\text { Mean }\end{array}$ & Rank & $\begin{array}{l}\text { IS } \\
\text { Staff } \\
\text { Mean }\end{array}$ & Rank & $\begin{array}{l}\text { IS } \\
\text { Manager } \\
\text { Mean }\end{array}$ & Rank \\
\hline Write coherently & 4.24 & 1 & 4.19 & 1 & 4.27 & 1 \\
\hline Use words correctly & 4.23 & 2 & 4.00 & 9 & 4.12 & 5.5 \\
\hline Use effective arrangement of ideas & 4.18 & 3 & 4.02 & 8 & 4.15 & 3.5 \\
\hline Write concisely & 4.17 & 4 & 4.06 & 5.5 & 4.04 & 8 \\
\hline Organize material well & 4.17 & 5 & 4.14 & 3 & 4.20 & 2 \\
\hline Write decisively & 4.16 & 6 & 4.06 & 5.5 & 4.12 & 5.5 \\
\hline Use grammar correctly & 4.13 & 7 & 4.15 & 2 & 4.15 & 3.5 \\
\hline Construct effective sentences & 4.13 & 8 & 4.05 & 7 & 4.09 & 7 \\
\hline Adapt material to the reader & 4.07 & 9 & 3.81 & 12 & 3.95 & 11 \\
\hline Use effective planning procedures & 4.02 & 10 & 3.76 & 14 & 3.83 & 18 \\
\hline
\end{tabular}


Advancing the IS Curricula: The Identification of Important Communication Skills

is more concerned with being able to understand the meaning of the message by having IS staff use words correctly in a logical arrangement.

The fact that all respondents rated ask appropriate questions and have effective oral communication skills as the two most important oral communication skills needed by IS staff in the project development process (see Table 3) indicates that these skills are needed to ensure successful system development. Rankings indicate that although having good presentation skills is important, it received the lowest rating by all participant types.

\section{TABLE 3: Important Oral Communication Skills \\ Needed By Information Systems Staff \\ (Rankings By Participant Type)}

\begin{tabular}{l|c|c|c|c|c|c}
\hline \multicolumn{1}{c|}{ Skill } & $\begin{array}{c}\text { IS } \\
\text { User } \\
\text { Mean }\end{array}$ & Rank & $\begin{array}{c}\text { IS } \\
\text { Staff } \\
\text { Mean }\end{array}$ & Rank & $\begin{array}{c}\text { IS } \\
\text { Manager } \\
\text { Mean }\end{array}$ & Rank \\
\hline Ask appropriate questions & 4.62 & 1 & 4.71 & 1 & 4.46 & 1 \\
\hline Have effective oral communication skill & 4.53 & 2 & 4.47 & 2 & 4.28 & 2 \\
\hline Use a clear, distinct, pleasant voice & 4.36 & 3 & 4.20 & 5 & 4.04 & 5 \\
\hline Organize ideas & 4.31 & 4 & 4.32 & 3 & 4.24 & 3 \\
\hline Use correct grammar & 4.21 & 5 & 4.21 & 4 & 4.12 & 4 \\
\hline Have good presentation skills & 4.12 & 6 & 4.03 & 6 & 3.91 & 6 \\
\hline
\end{tabular}

All respondent types consistently rated ability to accomplish assignments and ability to work cooperatively in a one-on-one and project team environment as the two most important interpersonal communication skills needed by IS staff in the systems development process (see Table 4).

\begin{tabular}{|c|c|c|c|c|c|c|}
\hline \multicolumn{7}{|c|}{$\begin{array}{l}\text { TABLE 4: Important Interpersonal Communication Skills } \\
\text { Needed By Information Systems Staff } \\
\text { (Rankings By Participant Type) }\end{array}$} \\
\hline Skill & $\begin{array}{l}\text { IS } \\
\text { User } \\
\text { Mean }\end{array}$ & Rank & \begin{tabular}{|l} 
IS \\
Staff \\
Mean
\end{tabular} & Rank & \begin{tabular}{|c|} 
IS \\
Manager \\
Mean
\end{tabular} & Rank \\
\hline Ability to accomplish assignments & 4.70 & 1 & 4.72 & 1 & 4.64 & 1 \\
\hline $\begin{array}{l}\text { Ability to work cooperatively in a one-on-one and } \\
\text { project team environment }\end{array}$ & 4.64 & 2 & 4.53 & 2 & 4.57 & 2 \\
\hline $\begin{array}{l}\text { Ability to plan and execute work in a collaborative } \\
\text { environment }\end{array}$ & 4.52 & 3 & 4.46 & 3 & 4.37 & 5 \\
\hline Ability to be self-directed and proactive & 4.44 & 4 & 4.38 & 4 & 4.55 & 3 \\
\hline $\begin{array}{l}\text { Ability to work closely with customers \& } \\
\text { maintain productive user/client relationships }\end{array}$ & 4.42 & 5 & 4.30 & 5 & 4.40 & 4 \\
\hline Ability to deal with ambiguity & 4.40 & 6 & 4.22 & 6.5 & 4.26 & 6 \\
\hline Ability to teach others & 4.33 & 7 & 4.22 & 6.5 & 3.94 & 8 \\
\hline $\begin{array}{l}\text { Ability to be sensitive to the organization's } \\
\text { culture/politics }\end{array}$ & 4.08 & 8 & 4.06 & 8 & 4.10 & 7 \\
\hline $\begin{array}{l}\text { Ability to develop and deliver effective, } \\
\text { informative, \& persuasive presentations }\end{array}$ & 4.04 & 9 & 3.62 & 9 & 3.72 & 9 \\
\hline
\end{tabular}


The consistent ranking by the IS staff and IS user of the ability to work cooperatively in a one-onone and project team environment and the ability to plan and execute work in a collaborative environment supports the importance for collaborative skills throughout the development process. Additionally, respondent types rated the ability to develop and deliver effective, informative, and persuasive presentations as being important but not as important as the other interpersonal communication skills deemed to be important. Thus, IS users, IS staff, and IS managers believe interpersonal skills involving self-direction and collaboration of IS staff are more important than their effective presentation skills in developing effective systems.

\section{Verifying Model Fit}

\section{Written communication skills}

The CFA of 36 written communication skill items from the data collected in this study revealed a primary component (single factor) solution comprised of 18 items. As discussed earlier, items that did not have at least a .50 loading were omitted from further analysis. Individual t-tests indicated that factor loadings of all the items were significant at the .0001 level. The composite reliability, or internal consistency reliability, score measured by Cronbach's alpha of the 18 items was .95, which exceeds the recommended minimum level of .70 (Hair et al, 1992). Therefore, there was empirical evidence of convergent validity. Overall, as shown in Table 5, the result of the CFA on the written communication skills variable indicated a good fit between model and

\begin{tabular}{|l|r|r|r|}
\hline \multicolumn{3}{|c|}{$\begin{array}{c}\text { TABLE 5: Written Communication Skills } \\
\text { Confirmatory Factor Analysis }\end{array}$} & $\begin{array}{l}\text { Cronbach } \\
\text { Ilpha } \\
.95\end{array}$ \\
\hline Write coherently & Loading & T-value & \\
\hline Use grammar correctly & .79 & 10.74 \\
\hline Write decisively & .86 & 11.44 \\
\hline Construct effective sentences & .88 & 11.68 \\
\hline Write concisely & .86 & 11.52 \\
\hline Write concretely & .84 & 11.26 \\
\hline Use punctuation correctly & .83 & 11.19 \\
\hline Have good proofreading skills & .87 & 28.76 \\
\hline Focus on reader rather than writer & .89 & 31.21 \\
\hline Organize material well & .70 & 15.99 \\
\hline Have effective revising skill & .75 & 18.09 \\
\hline Perform effective audience analysis & .86 & 25.96 \\
\hline Use correct letter format & .78 & 12.38 \\
\hline Write extemporaneously & .82 & 13.14 \\
\hline Know psychological aspects of writing & .85 & 13.60 \\
\hline Use ideas subordination effectively & .89 & 14.25 \\
\hline Avoid use of jargon & .72 & 13.99 \\
\hline Write effective thesis statements & .72 & 11.50 \\
\hline
\end{tabular}


Advancing the IS Curricula: The Identification of Important Communication Skills

data (with chi-square/degrees of freedom $=3.62$; RMR $=.05$, CFI $=.95$; NNFI $=.92$; NFI $=.89$ ). Both CFI and NNFI were above the recommended minimum of .90 , and NFI $=.89$ was very close to .90. The RMR of .05 is small (i.e., less than .10), as recommended by Kline (1998), and chi-square/degrees of freedom $=3.62$ is smaller than the limit of 5 (Kline, 1998).

The 18 items revealed in the primary factor solution were compared to the composite weighted averages of the 36 writing competencies that business employees perceived to be important in Quible's study (1991). The comparison showed that 11 of the 18 items retained in this study were among the top-ranked 20 most important writing competencies in Quible's study. In Quible's study, the top-ranked 20 items had average ratings between very important (highest rating) and quite important (second highest rating). The current findings were compared also to another study that used Quible's 36 writing competencies and that sampled graduates of a university in the southeastern United States (Patrick \& Carr, 1993). Of the 259 respondents in that study, 70 were Computer Information Systems alumni who were either MIS managers, programmers, or systems analysts; 108 respondents in the current study were programmers or systems analysts. Nine of the 18 written communication skill factor items revealed in the current study matched items ranked in the top 15 writing competencies of Patrick \& Carr's study. Thus, the CFA procedure and comparison with other studies indicated the 18-item, single-factor structure was acceptable for describing the variable written communication skills. In other words, those 18 items identified in Table 5 make up the written communication skill variables identified by the IS users, IS staff, and IS managers in this study as being those written skills that need to be enhanced for successful system development.

\section{Oral communication skills and interpersonal skills}

A priori in this study, oral communication and interpersonal skills were presumed to be two different and distinct variables. Yet, some researchers have used a single definition of either oral or interpersonal communication to include both. For example, Leitheiser (1992) defined interpersonal skill categories to include listening, working with others, working alone, persuading, presenting, responding to emotions, and training. To determine whether the oral and interpersonal skills variables would emerge as two factors, the categories were combined initially for tests of structure.

From Table 6, one can see that CFA analysis indicated oral communication skills and interpersonal skills are two unique factors. The CFA results indicated that all six of the oral communication skill items had a minimum .50 loading on a single factor and no higher than a .35 loading on another factor. T-tests showed that all six oral communication items were significant at the .0001 level. The internal reliability coefficient of the oral communication construct was .82, higher than the recommended minimum of .70 for testing homogeneity of items. Thus, there was evidence of convergent validity, and it was concluded that the six oral communication items were measuring the same construct. The items in the oral communication construct compare favorably with the most prevalent communication inadequacies of job applicants identified by personnel interviewers (Peterson, 1997), including topic relevance; response organization; and response clarity, grammar, and feedback.

Furthermore, CFA results indicated that two of the nine interpersonal skill items should be dropped from further analysis because they did not have at least a .50 loading on a factor. Each remaining item had a minimum .50 loading on a single factor different from the oral communication skill items, and each had no higher than a .35 loading on another factor. All seven t-tests were significant at the .0001 level. The internal reliability coefficient of the interpersonal skill items was .82, higher than the recommended minimum of .70 for testing homogeneity of items. Therefore, there was evidence of convergent validity, and it was concluded that the seven interpersonal skill items were measuring the same construct. No confidence interval test included 1.0; 
TABLE 6: Oral Communication and Interpersonal Skills Confirmatory Factor Analysis

\begin{tabular}{|c|c|c|c|}
\hline Item & Loading & T-value & $\begin{array}{c}\text { Cronbach } \\
\text { Alpha }\end{array}$ \\
\hline Oral Communication Skills & & & .82 \\
\hline Have effective oral communication skill & .64 & 10.82 & \\
\hline Ask appropriate questions & .50 & 7.29 & \\
\hline Use a clear, distinct, pleasant voice & .76 & 13.59 & \\
\hline Use correct grammar & .78 & 14.04 & \\
\hline Organize ideas & .67 & 11.49 & \\
\hline Have good presentation skills & .77 & 13.78 & \\
\hline
\end{tabular}

Interpersonal Skills

Ability to plan and execute work in a collaborative environment

Ability to deal with ambiguity

Ability to work closely with customers and maintain productive user/client relationships Ability to accomplish assignments Ability to teach others Ability to be self-directed and proactive Ability to be sensitive to organization's culture/politics

\begin{tabular}{|c|c|}
\hline .66 & 10.97 \\
\hline .71 & 12.06 \\
\hline .51 & 7.60 \\
\hline .67 & 11.28 \\
\hline .65 & 10.90 \\
\hline .68 & 11.51 \\
\hline .64 & 10.68 \\
\hline
\end{tabular}

therefore, the oral communication skills scale seems to identify a construct that is different from the interpersonal skills construct.

Overall, the result of the CFA on the oral communication skills and interpersonal skills variables indicated a good fit between model and data (chi-square/d.f. $=2.75$ was less than $5 ; \mathrm{RMR}=.04$ was less than .10 ; CFI $=.91$ and NNFI $=.91$ were greater than .90 ; and NFI $=.86$ was slightly less than .90). Also, the interpersonal skills' overall internal reliability coefficient of .83 compared favorably with the .89 reliability coefficient of the interpersonal construct of Lee, Trauth, and Farwell (1995). The series of tests applied to the CFA results provided support for the validity and reliability of the oral communication skills and interpersonal skills constructs. Thus, the CFA identified six oral communication skills and seven interpersonal skills that IS educators should strive to enhance within the IS curriculum to encourage more effective skills development by IS students.

\section{Conclusions and Implications}

Although research (Clark, 2002; Jiang \& Klein, 1999) indicates communication is important between IS staff, users, and IS managers to ensure successful development projects, the ineffective communication skills of IS staff are often cited as a possible cause of failed IS projects. Since effective communication between IS staff and other project development stakeholders is critical to project success, this study examined specific written, oral, and interpersonal communication skills that IS staff, IS users, and IS managers perceived to be the most important during the systems development process. 
Advancing the IS Curricula: The Identification of Important Communication Skills

The rankings by IS users, IS staff, and IS managers, as presented in this study, indicated that the three stakeholder groups had similar views of critical written, oral, and interpersonal communication skills needed by IS staff in the systems development process. Overall, the rigorous statistical analysis using CFA of the three communication skill types - written, oral, and interpersonalsupported the rankings of important communication skills needed by IS staff.

This research adds to the body of IS knowledge by describing a survey of communication skills needed by IS staff during systems development. The survey consists of 18 written communication skill items, 6 oral communication skill items, and 7 interpersonal communication skill items that IS project development stakeholders (IS staff, users, and IS managers) perceive to be important. Respondents consistently identified the most important writing skill as coherent writing, the two most important oral communication skills as the ability to ask appropriate questions and have effective oral communication skills, and the two most important interpersonal skills as the ability to accomplish assignments and the ability to work cooperatively in a one-on-one and project team environment. This research enhances two studies that identified and verified an overall skill set (technical, behavioral, and managerial) needed by IS staff (Lee, Trauth, \& Farwell, 1995; Noll \& Wilkins, 2002).

Previous research (Clark, 2002) has shown a critical link between effective communication and IS project development success. Using the written, oral, and interpersonal skill sets derived in this study, IS faculty can focus on helping students develop those specific communication skills that enhance project development in the IS curriculum. Since researchers have indicated that the IT curriculum should be adapted to place emphasis on important skills (Mann, 2002) and "to provide various knowledge and skills in proportion to the quantity demanded by customers" (Yen, Lee, \& Koh, 2001, p. 432), IS faculty should revisit their IS curriculum. Thus, results of this study suggest IS programs could be changed to incorporate the following:

- Encourage business faculty to require independent and collaborative written and oral communication assignments in core business courses to enhance IS students' written communication skills, oral communication skills, and collaborative skills. These types of assignments will encourage IS student interaction with other business students-who may eventually become IS users - and enhance the IS student's ability to work with others in defining and arriving at a common set of goals and in producing a finished product.

- Require IS students to take a business communication course wherein students can refine their written and oral communication skills within the business context. By preparing effective written business documents, such as memorandums, letters, and reports, IS students will develop those important communication skills identified in this study. Additionally, by making presentations in a business communication course, IS students will expand their ability to communicate effectively orally.

- Require IS faculty to include various written, oral, and collaborative assignments within all IS courses. Integrating appropriate written, oral, and interpersonal communication vignettes into IS content areas will provide experiential exercises to expand IS students' communication abilities. Additionally, by requiring students to submit assignments in writing, IS educators are helping students to enhance those written skills identified in this study. And, if IS students are required to ask questions of other students when oral presentations are made, those students who are listening to a presentation and those students giving a presentation are developing the identified oral communication skills in addition to critical thinking skills. Furthermore, by working on collaborative assignments, IS students are enhancing those important identified interpersonal communication skills.

Attention to promoting effective communications in IS graduates through the development of written, oral, and interpersonal communication skills identified in this research will likely lessen 
the degree of project risk associated with poor communication among stakeholders. By changing the IS curriculum to encourage the development of the identified communication skills, future IS staff will be better prepared to build successful systems through a collaborative process with IS users.

\section{Study Limitations}

Although the CFA procedure and comparisons with other studies provided support for the validity and reliability of the proposed constructs developed for important written, oral, and interpersonal communication skills, the following limitations of this study need to be recognized because they may limit the generalizability of the findings of this study.

- A convenience sample was drawn from Southeastern United States. Although communication skills needed by IS project developers may be similar universally, the geographic confinement of the sample might make the findings less generalizable.

- The sample was obtained by contacting IS directors and prospective participants. This sample selection process may contain a selection bias since IS directors obtained handselected groups for participation and individual participants solicited the other two group participants.

- Only three types of individuals participating in a system development project-an IS manager, IS staff, and IS user-rather than all individuals who participated throughout the development project completed questionnaires. No attempt was made to include all members of a project development team. Thus, the perceptions of the participants reported in this study may not reflect the perceptions of all individuals who participated throughout the systems development process.

\section{References}

Averett, P. (2001, Summer). People: the human side of systems technology. The Journal for Quality and Participation, 24 (2), 34-37.

Bennett, J. (1999, April). Achieving professional excellence for a new century. Information Management Journal, 33, 36-42.

Campbell, D. \& Fiske, D. (1959). Convergent and discriminant validation by the multitrait-multimethod matrix. Psychological Bulletin, 56 (2), 81-105.

Cronbach, L. (1951). Coefficient alpha and the internal structure of tests. Psychometrika, 16, 297-334.

Clark, M. (2002). IT project failure is rampant: study. Retrieved February 28, 2003 from http://www.electricnews.net/news.html?code=8833536

Daft, R. (1994). Management, ( ${ }^{\text {rd }}$ Ed.). Fort Worth: Harcourt, Brace.

Ehie, I. C. (2002). Developing a management information systems (MIS) curriculum: Perspectives from MIS practitioners. Journal of Education for Business, 77 (3), 151-159.

Ewusi-Mensah, K. (1997). Critical issues in abandoned information systems development projects. Communications of the ACM, 40 (9), 74-82.

Freeman, R. E. (1986). Strategic management: A stakeholder approach, Boston: Pitman Publishing.

Gorgone, J., Davis, G., Valacich, J., Topi, H., Feinstein, D., \& Longenecker, H. (2002). IS’ 2002: Model curriculum and guidelines for undergraduate degree programs in information systems. Retrieved on September 19, 2003, from www.is2002.org

Guinan, P. J. (1988). Patterns of excellence for IS professionals-An analysis of communication behavior, Washington DC: International Center for Information Technologies. 
Advancing the IS Curricula: The Identification of Important Communication Skills

Hair, J., Anderson, R., Tatham, R., \& Black, W. (1992). Multivariate data analysis with readings, ( $3^{\text {rd }}$ ed.). New York: Macmillan Publishing Company.

Igbaria, M. \& Baroudi, J. (1995). The impact of job performance evaluations on career advancement prospects: an examination of gender differences in the IS workplace. MIS Quarterly, 19 (1), 107-123.

Jensen, M. \& Meckling, W. (1976). Theory of the firm: managerial behavior, agency costs, and ownership structure. Journal of Financial Economics, 3 (3), 305-360.

Jiang, J. \& Klein, G. (1999). User evaluation of information systems: By system typology. IEEE Transactions on System, Man, and Cybernetics, 29 (1), 111-116.

Jiang, J., Klein, G. \& Sobol, M. G. (2000). Performance ratings and importance of performance measures for IS staff: The different perceptions of IS users and IS staff. Working Paper. Ruston, LA: Louisiana Tech University College of Business and Administration.

Kline, R. B. (1998). Principles and practice of structural equation modeling, New York: The Guilford Press.

Kohli, R. \& Grupta, J. (2002, July-Sept). Effectiveness of systems analysis and design education: an exploratory study. Journal of End User Computing, 14 (3), 16-33. Retrieved on January 10, 2003, from Infotrac. Galegroup database.

Lee, D. M., Trauth, E. M., \& Farwell, D. (1995). Critical skills and knowledge requirements of IS professionals: A joint academic/industry investigation. MIS Quarterly, 19 (3), 313-340.

Leitheiser, R. L. (1992). MIS skills for the 1990s: A survey of MIS managers' perceptions. Journal of Management Information Systems, 9 (1), 69-80.

Locke, E. A. (1969). What is job satisfaction? Organizational Behavior and Human Performance, 4 (3), 309-336.

Maes, J. D., Weldy, T. G., \& Icenogle, M. L. (1997). A managerial perspective: Oral communication competency is most important for business students in the workplace. The Journal of Business Communication, 34 (1), 67-80.

Mann, J. (2002). IT education's failure to deliver successful information systems: Now is the time to address the IT-user gap. Journal of Information Technology Education, 1 (4), 253-267.

Mintzberg, H. (1997). The nature of managerial work. New York: Addison-Wesley Educational Publishers.

Noll, C. L. \& Wilkins, M. (2002). Critical skills of IS professionals: a model for curriculum development. Journal of Information Technology Education, 1 (3), 143-154.

Patrick, A., \& Carr, D. (1993). The perceived importance of writing competencies as perceived by College of Business alumni and students. Journal of Computer Information Systems, 34 (1), 73-76.

Peterson, M. (1997). Personnel interviewers' perceptions of the importance and adequacy of applicants' communication skills. Communication Education, 46 (4), 287-291.

Quible, Z. K. (1991). Writing competencies needed by business employees. Delta Pi Epsilon Journal, 33 (1), 35-51.

Snoke, R. \& Underwood, A. (2001). Generic attributes of IS graduates-a comparison of Australian industry and academic views. Journal of Global Information Management, 9(2), 34-42.

Suchan, J. \& Dulek, R. (1998). From text to context: An open systems approach to research in written business communication. The Journal of Business Communication, 35 (1), 87-110.

'Time to share risks' outsourcers advised. (1999, February 18). Computer Weekly, p. 8.

Verespej, M. (1999). Be your own force. Industry Week, 248 (12), 22.

Yen, D., Lee, S., \& Koh, S. (2001). Critical knowledge/skill sets required by industries: an empirical analysis. Industrial Management + Data Systems, 101 (8/9), 432-442. 


\section{Biographies}

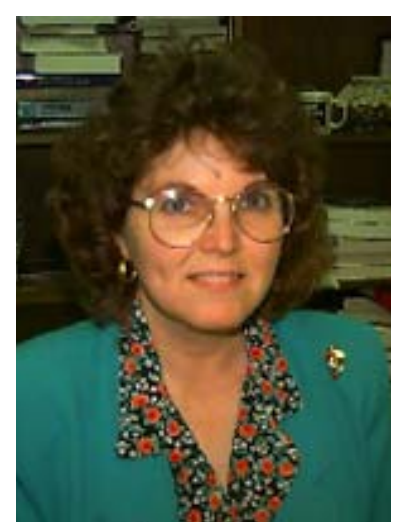

Ruth A. Miller is an assistant professor of computer information systems at the University of Louisiana at Monroe and is the Kitty DeGree Endowed Professor in Computer Information Systems. She holds the Doctor of Business Administration from Louisiana Tech University. She teaches e-commerce, networking, and principles of management information systems. Her research interests include knowledge and skill requirements of information systems professionals, networking, e-commerce in small and medium-size businesses, and technology implementation in education.

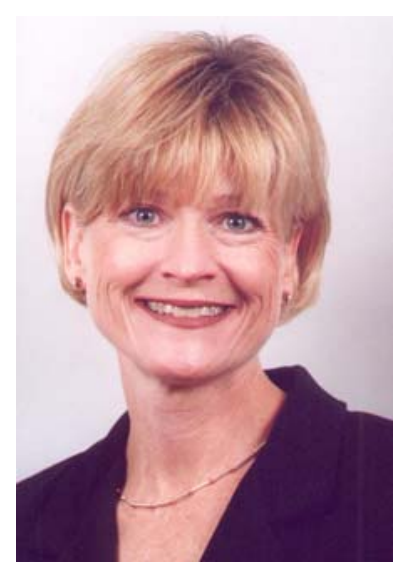

Donna W. Luse is the Associate Dean of the College of Business Administration and Professor of Business Communications at the University of Louisiana at Monroe. She holds the Doctor of Philosophy from the University of North Texas. She teaches undergraduate courses in managerial communication and business communication and a graduate course in research and presentations. In addition to co-authoring a textbook on business communication, Dr. Luse has published over 30 articles in professional publications. Her research interests include communication skill requirements of business graduates, including information systems professionals, and the implementation and effectiveness of technology in education. 